\title{
Evaluation of Phenolic Compounds Content and Antioxidant Capacity of Some Medicinal Plants, Potentially Used for Their Preventive Role Against Various Oral Diseases
}

\author{
GABRIELA CIAVOI ${ }^{1}$, TUNDE J URCA ${ }^{2}$, BIANCA PASCA ${ }^{2}$, EDWIN SEVER BECHIR ${ }^{3 *}$, CAMELIA MRAZ ${ }^{4}$, CLAUDIA J URCA $^{4}$, \\ RITA KISS ${ }^{5}$, FELICIA MARC ${ }^{6}$, ANNAMARIA PALLAG ${ }^{2}$ \\ 'University of Oradea, Faculty of Medicine and Pharmacy, Dental Medicine Department, 10, 1 Decembrie Sq., 410073, Oradea, \\ Romania \\ ${ }^{2}$ University of Oradea, Faculty of Medicine and Pharmacy, Pharmacy Department, 29 Nicolae Jiga Str., 410028, Oradea, Romania \\ ${ }^{3}$ University of Medicine, Pharmacy, Sciences and Technology of Targu Mures, Faculty of Dental Medicine, 38 Gheorghe Marinescu \\ Str., 540142, Targu Mures, Romania \\ ${ }^{4}$ University of Oradea, Faculty of Medicine and Pharmacy, Preclinical Disciplines, 10, 1 Decembrie Sq, 410073, Oradea, Romania \\ ${ }^{5}$ University of Debrecen, Faculty of Medicine, Department of Pharmacology and Pharmacotherapy, Nagyerdeikrt. 98, H-4032 \\ Debrecen, Hungary \\ ${ }^{6}$ University of Oradea, Faculty of Medicine and Pharmacy, Medical Disciplines Department, 10, 1 Decembrie Sq., 410073, Oradea, \\ Romania
}

\begin{abstract}
The oral cavity diseases represent a public health issue. Antioxidants have an important role in the prevention of these diseases. In this study we tested different types of plants in order to evaluate the compounds with antioxidant capacity and in order to create a topical product which prevents oral cavity diseases. Phenolic compounds and flavonoids were analyzed in four different species of medicinal plants from spontaneous flora of Bihor County. The antioxidant capacity of the extracts was evaluated by: CUPRAC assay, ABTS method and FRAP method. Our results show that the studied medicinal plants represent rich sources of compounds with antioxidant capacity, especially Polygonum aviculare and Fumaria officinalis.
\end{abstract}

Keywords: phenolic compounds, flavonoids, antioxidant capacity, oral cavity diseases

One of the public health issues are the oral cavity diseases. A good balance of oxidants and antioxidants is important for oral health and for systemic health too [1].

Different chemical and pharmaceutical waste pollutants [2] (e.g. alcohol, nicotine, superoxide, hydrogen peroxide, antibiotics, hydroxyl radicals, etc.) are factors that can disturb the balance of oxidants in oral tissues, causing oxidative stress [3-9]. Recent studies on antioxidants have demonstrated their important role in offsetthis imbalance [10,11]. Many antioxidant compounds possess antiinflammatory, antiatherosclerotic [12], antiproliferative, antitumor [13], antimutagenic, anticarcinogenic, antibacterial or antiviral activities [1318]. An important group of antioxidants are phenolic compounds $[10,12]$. Several thousands of natural phenolic compounds have been identified in plants, some of them being obtained in aromatic plants distillation [19]. Thereare classified in two groups: flavonoids and non-flavonoids [20-23].

People are familiar with antioxidants taken systemically, such as foods and vitamin supplements, but topical antioxidants may have action on oral mucosa cells. Research studies are currently under way to examine the effectiveness of combinations of antioxidants applied topically to oral cells. Results from clinical studies, though incomplete, are positive. In addition, published studies confirmed that antioxidants that work on skin cells also have an effect on oral, gingival, and periodontal cells [1,3$9,11]$.

In this study we tested four different species of medicinal plants from unpolluted spontaneous flora of Bihor County in order to evaluate the compounds with antioxidant capacity and in order to create a topical pharmaceutical formulation which could be used to prevent the oral cavity diseases.

\section{Experimental part \\ Plant material}

We performed a comprehensive study in which we followed, during 2017, in eight different areas, from Bihor county of Romania, the spontaneous medicinal plants populations. The aerial parts of creeping jenny, Glechoma hederacea (Lamiaceae Family); common knotgrass, Polygonum aviculare (Polygonaceae Family); common fumitory, Fumaria officinalis (Fumariaceae Family); red clover, Trifoliumpratense (Fabaceae Family) were studied. They were collected from three different unpolluted regions of Oradea area $(01,02,03)$, Beiu' area $(B 1, B 2, B 3)$, and two different unpolluted regions of $\mathrm{Cefa}$ area $(\mathrm{C} 1, \mathrm{C2})$. The identified areas $01,02,03, \mathrm{~B} 1, \mathrm{~B} 2, \mathrm{~B} 3$ are placed in wooded areas, with clayey soil. The area $\mathrm{Cl}$ and $\mathrm{C2}$, are in areas with sandy, wet soil.

In case of Glechoma hederacea and Polygonum aviculare, we harvested the flow ering stems and leaves, in each area, between April and June 2017. Between May and July 2017 in case of Fumaria officinalis and Trifoliumpratensewe harvested the flowering stems and leaves, in each area, between May and July 2017. We harvested the studied plants in different times of the year due to the differences in their periods of maximum development and flowering.

A specimen from each of the studied species was deposited in the Pharmaceutical Botany Herbarium of Faculty of Medicine and Pharmacy Oradea. Plant materials were dried at room temperature and ground before extraction. We used plant extracts to measure the total 
quantity of phenolic acids and flavonoids. After that we evaluated the antioxidant capacity of the extracts.

\section{Study of the bioactive compounds of plant extracts}

The determination of total phenolic contents using FolinCiocalteu method

The alcoholic extract solutions(tinctures) were prepared by maceration in $70^{\circ}$ alcohool, at room temperature $(20$ $\left.{ }^{\circ} \mathrm{C}\right)$ for 10 days. The residue was removed by decantation. Total phenolic contents were determined by using the FolinCiocalteu reagen $[14,24]$ by using Gallic acid as standard, with some modifications. The extract solution $(0.1 \mathrm{~mL})$ containing $1000 \mu \mathrm{g}$ of extract was mixed with $46 \mathrm{~mL}$ distilled water in a volumetric flask and $1 \mathrm{~mL}$ FolinCiocalteu (Merck) reagent was added; the flask was thoroughly shaken. The mixture was allow ed to react for 3 minutes and $3 \mathrm{~mL}$ aqueous solution of $2 \% \mathrm{Na}_{2} \mathrm{CO}_{3}$ were added. At the end of the $2 \mathrm{~h}$ incubation at the room temperature, the absorbance of each mixture was measured at $765 \mathrm{~nm}$, in Shimadzu UV-1700 Pharmaspec UV-Vis Spectrophotometer. The same procedure was also applied to the standard solutions of Gallic acid, and a standard curve was obtained.

With the Folin-Ciocalteu method we measured the $\mathrm{OH}$ groups of the samples taken into study in alkaline conditions (adjusted with sodium carbonate). The absorbance at the $765 \mathrm{~nm}$ wavelength increases proportional with the number of $\mathrm{OH}$ groups of the anthocyanins. The calibration curve (fig.1) was obtained with a solution of known concentration of gallic acid (20$100 \mathrm{ppm}$ ), and the concentration of polyphenol extracts was calculated from the regression equation and expressed as mg Gallic acid equivalents (GAE) / 100 g dry sample $[14,24,25]$.

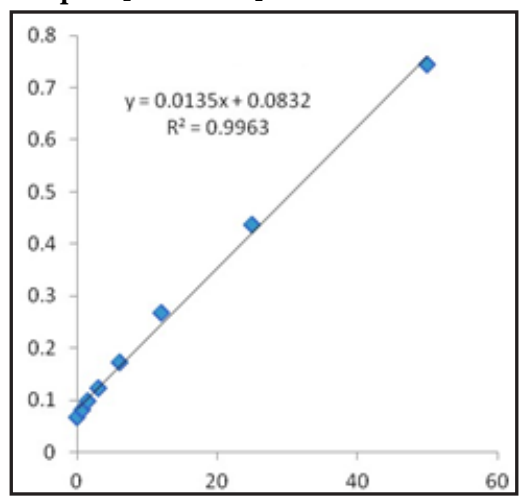

Fig. 1. The calibration curve made with Gallic acid for FolinCiocalteu method in alcoholic medium

The determination of total flavonoid contents

The content of total flavonoids was determined by using a colorimetric method which has been described previously [25-28]. $1 \mathrm{~mL}$ of the sample (containing $0.1 \mathrm{mg}$ $/ \mathrm{mL}$ dry weight) is mixed with $4 \mathrm{~mL}$ water and placed in a $10 \mathrm{~mL}$ volumetric flask.

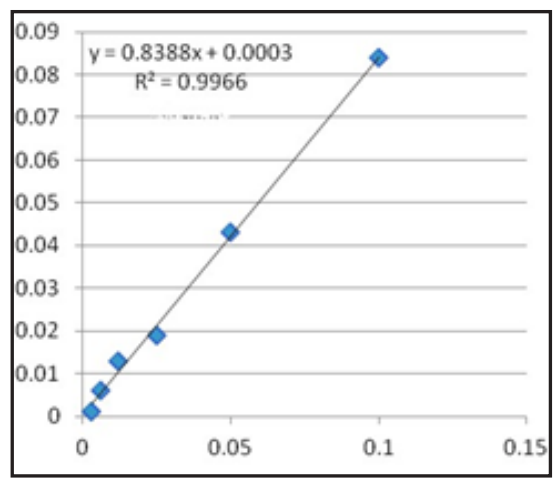

Fig. 2. Calibration curve made with quercetin in alcoholic medium (surroundings, environment)
First there were added $0.3 \mathrm{~mL}$ ground $\mathrm{NaNO}_{2} 5 \%$, after five min $0.3 \mathrm{~mL} \mathrm{AlCl}, 10 \%$ and after $6 \mathrm{~min}, 2 \mathrm{~mL}^{2}$ of $\mathrm{NaOH}$ $1 \mathrm{M}$. The volumetric flask is filled to the mark with distilled water. The solution is mixed in the volumetric flask and it is read the absorbance at $510 \mathrm{~nm}$ in the Shimadzu UV1700 Pharmaspec UV-Vis spectrophotometer. The calibration curve (fig. 2) shall create its standard using quercetin (QE) [29-31].

\section{Study of the antioxidant capacity. FRAP method (Ferric Reducing Antioxidant Power)}

FRAP method is a simple spectrophotometric method that assesses the antioxidant power of the studied samples, being based on the reduction of ferric tripyridyltriazine complex [Fe(III)-TPTZ] by a reductant, at an acid pH. The stock solutions included: $300 \mathrm{mM}$ acetate buffer; $270 \mathrm{mg}$ $\mathrm{FeCl}_{2} \cdot 6 \mathrm{H}_{2} \mathrm{O}$ dissolved in $50 \mathrm{~mL}$ distillated water; $150 \mathrm{mg}$ TPTŻ and $150 \mu \mathrm{l} \mathrm{HCl}$, dissolved in $50 \mathrm{~mL}$ distillated water. The working FRAP solution was freshly prepared by mixing $50 \mathrm{~mL}$ acetate buffer, $5 \mathrm{~mL} \mathrm{FeCl} \cdot 6 \mathrm{H}_{2} \mathrm{O}$ solution and $5 \mathrm{~mL}$ TPTZ solution. Trolox was used as a standard solution, the calibration curve was made for concentrations between $0-300 \mu \mathrm{M}$, having the correlation coefficient $\mathrm{R}^{2}=0.9956$ and the regression equation $(y=0.0017 x+0.0848)$, where $y$ represents the absorbance detected at $595 \mathrm{~nm}$. The results are expressed as $\mu \mathrm{mol}$ Trolox equivalents (TE)/100 $\mu \mathrm{L}$ extract [32,33].

\section{CUPRAC assay (Cupric lons ( $\mathrm{Cu}^{2+)}$ Reducing Power)}

In order to determine the cupric ions $\left(\mathrm{Cu}^{2+}\right)$ reducing antioxidant capacity the method proposed by Karaman et al. (2010) was used with slight modifications [34]. To this end, $0.25 \mathrm{~mL} \mathrm{CuCl}$, solution (0.01 M), $0.25 \mathrm{~mL}$ ethanolic neocuproine solution $\left(7.5 \times 10^{-3} \mathrm{M}\right)$ and $0.25 \mathrm{~mL}$ $\mathrm{CH}_{3} \mathrm{COONH}_{4}$ buffer solution (1 M) were added to a test tube, follow ed by mixing with the plants extracts. The total volume was adjusted to $2 \mathrm{~mL}$ with distilled water and thoroughly mixed. The tubes were stoppered and kept at room temperature. Absorbance was measured at $450 \mathrm{~nm}$ against a reagent blank, 30 min later. Increased absorbance of the reaction mixture indicates increased reduction capability [35-37].

\section{ABTS Method (Determination of Antioxidant Capacity using the ABTSÿ+Radical Cation)}

The test method of antiradical capacity, with the application of ABTS (2,2-azinobis-3-ethylbenzothiazoline6 -sulfonic acid) is known and widely used to determine the antioxidant activity of substances of whatever nature. Based on the given method, it was determined the antioxidant activity of both pure substances, and antioxidant complexes. The ABTSÿ ${ }^{+}$radical is generated by the oxidation of ABTS with potassium persulfate and is reduced by the addition of hydrogens atom.

ABTS method or TEAC (Trolox Equivalents Antioxidant Capacity) is based on the ability of antioxidants to reduce the life of the cation radical $\left(\mathrm{ABTS}^{+}\right)$, a green - blue chromophore that absorbs at $734 \mathrm{~nm}$, compared to Trolox. $\mathrm{ABTS}^{+}$is produced by reacting stock solution ABTS $-2,2$ Azinobis-( 3 ethyl 6 sulfonic acid) ( $7 \mathrm{mM}$ ) with potassium persulfate $(2.45 \mathrm{mM})$ for $12-16 \mathrm{~h}$. In order to study the antioxidant activity, $\mathrm{ABTS}^{+}$solution is diluted with ethanol until an absorbance of $0.70 \pm 0.02$ to $734 \mathrm{~nm}$ is obtained. After the addition of $100 \mu \mathrm{L}$ of sample to $2900 \mu \mathrm{L} \mathrm{ABTS}+$ solution, the mixture was monitored spectrophotometrically at $734 \mathrm{~nm}$. The calibration curve was made with the Trolox standard $[15,16,26,38-40]$.The calculation formula is the same as for the DPPH test.The reduction of 
the extinction values (\% Inhibition) of the DPPH solution is calculated according to the equation:

$\%$ Inhibition $=\left(A b S_{D P P H}-A b S_{\text {SAMPLE }}\right) / A b S_{D P P H} \times 100$

\section{Results and discussions}

\section{Bioactive compounds of plant extracts}

The total amount of polyphenols, determined by the Folin-Ciocalteu method, is highest in Polygonum aviculare, followed by Fumaria officinalis, Glechoma hederacea, and Trifoliumpratense, but we also obtained high values in the cases of other species introduced in the study, as it can be seen in table 1.

In the same time, total flavonoid content is the highest in Polygonum aviculare followed by Fumaria officinalis, Glechoma hederacea and Trifoliumpratense, as it can be seen in table 2.

\section{Antioxidant capacity}

After analyzing the total polyphenolic content and the total flavonoid content, we determined the areas with the highest values, in case of Glechoma hederacea area01, in case of Polygonumavicularearea 03 , in case of Fumaria officinalis area B1 and in case of Trifolium pratense area B1 (tables 1 and 2). From extracts obtained from plants harvested in the respective areas we evaluate the antioxidant capacity by: CUPRAC assay, ABTS method and FRAP methodas it can be seen in figures 3,4 , and 5 .

The obtained results by using those three methods of determining the antioxidant capacity, showed that the ethanol extracts obtained from the Polygonumaviculare from 03 area and Fumaria officinalis from B1 area, have shown a high capacity of reducing ABTS, FRAP and CUPRAC radicals, at the beginning of the vegetation period in April and May.

Dentists around the world are of particular interest in the treatment of orofacial system diseases with new, herbal-available pharmaceutical formulations [41-43].

\begin{tabular}{|c|c|c|c|c|c|c|c|c|}
\hline Month & O1 & O2 & O3 & B1 & B2 & B3 & C1 & C2 \\
\hline \multicolumn{8}{|c|}{ Glechoma hederacea } \\
\hline April & 368.17 & 324.65 & 327.15 & 311.97 & 301.45 & 320.55 & 225.16 & 240.64 \\
\hline May & 362.65 & 361.37 & 352.66 & 309.46 & 272.73 & 241.237 & 248.20 & 272.17 \\
\hline June & 350.31 & 351.07 & 340.71 & 321.24 & 330.57 & 303.411 & 247.05 & 223.35 \\
\hline \multicolumn{8}{|c|}{ Polygonum aviculare } \\
\hline April & 401.45 & 430.78 & 454.60 & 321.78 & 342.52 & 314.51 & 360.27 & 313.48 \\
\hline May & 378.72 & 412.34 & 432.05 & 332.27 & 345.15 & 327.80 & 280.36 & 320.54 \\
\hline June & 390.55 & 387.35 & 397.06 & 332.46 & 298.23 & 324.56 & 365.32 & 292.00 \\
\hline \multicolumn{8}{|c|}{ Fumania officinalis } \\
\hline May & 392.65 & 361.37 & 352.66 & 309.46 & 272.73 & 241.23 & 266.32 & 172.06 \\
\hline June & 350.31 & 351.07 & 340.71 & 321.24 & 330.57 & 303.41 & 260.77 & 213.48 \\
\hline July & 328.17 & 324.65 & 327.15 & 311.97 & 301.45 & 320.55 & 250.36 & 220.24 \\
\hline \multicolumn{8}{|c|}{ Trifoliumpratense } \\
\hline May & 232.75 & 281.30 & 331.16 & 342.60 & 303.24 & 341.37 & 266.32 & 172.06 \\
\hline June & 320.15 & 328.00 & 304.41 & 329.34 & 280.71 & 362.41 & 260.77 & 213.48 \\
\hline July & 218.27 & 227.25 & 271.22 & 270.19 & 247.14 & 276.52 & 250.36 & 220.24 \\
\hline
\end{tabular}

Table 1

TOTAL POLYPHENOLIC CONTENT IN MEDICINAL PLANTS TESTED (mgGAE) 100 DW)

\begin{tabular}{|c|c|c|c|c|c|c|c|c|}
\hline Months & 01 & $\mathrm{O} 2$ & 03 & B1 & $\mathrm{B} 2$ & $\overline{B 3}$ & C1 & $\mathrm{C} 2$ \\
\hline \multicolumn{9}{|c|}{ Glechoma hederacea } \\
\hline April & 28 & 23 & 25 & 24 & 25 & 27 & 22 & 23 \\
\hline May & 28 & 28 & 26 & 24 & 23 & 28 & 20 & 21 \\
\hline June & 25 & 26 & 23 & 25 & 21 & 24 & 17 & 19 \\
\hline \multicolumn{9}{|c|}{ Polygonum aviculare } \\
\hline April & 33 & 36 & 38 & 34 & 35 & 34 & 27 & 26 \\
\hline May & 30 & 32 & 35 & 34 & 30 & 30 & 25 & 25 \\
\hline June & 29 & 28 & 32 & 30 & 27 & 30 & 25 & 25 \\
\hline \multicolumn{9}{|c|}{ Fumaria officinalis } \\
\hline May & 26 & 29 & 29 & 36 & 33 & 32 & 25 & 26 \\
\hline June & 28 & 27 & 29 & 32 & 29 & 29 & 21 & 25 \\
\hline July & 25 & 27 & 28 & 31 & 28 & 28 & 20 & 22 \\
\hline \multicolumn{9}{|c|}{ Trifoliumpratense } \\
\hline May & 30 & 26 & 29 & 29 & 28 & 28 & 27 & 25 \\
\hline June & 27 & 24 & 25 & 24 & 27 & 25 & 22 & 25 \\
\hline July & 25 & 24 & 25 & 23 & 25 & 24 & 19 & 22 \\
\hline
\end{tabular}

Table 2

TOTAL FLAVONOID CONTENT IN MEDICINAL PLANTSTESTED (mgQE) $100 \mathrm{DW})$
Fig. 3. Capacity of reducing FRAP radicals (FRAP $\mathrm{mgTE} / \mathrm{mL}$ ) 

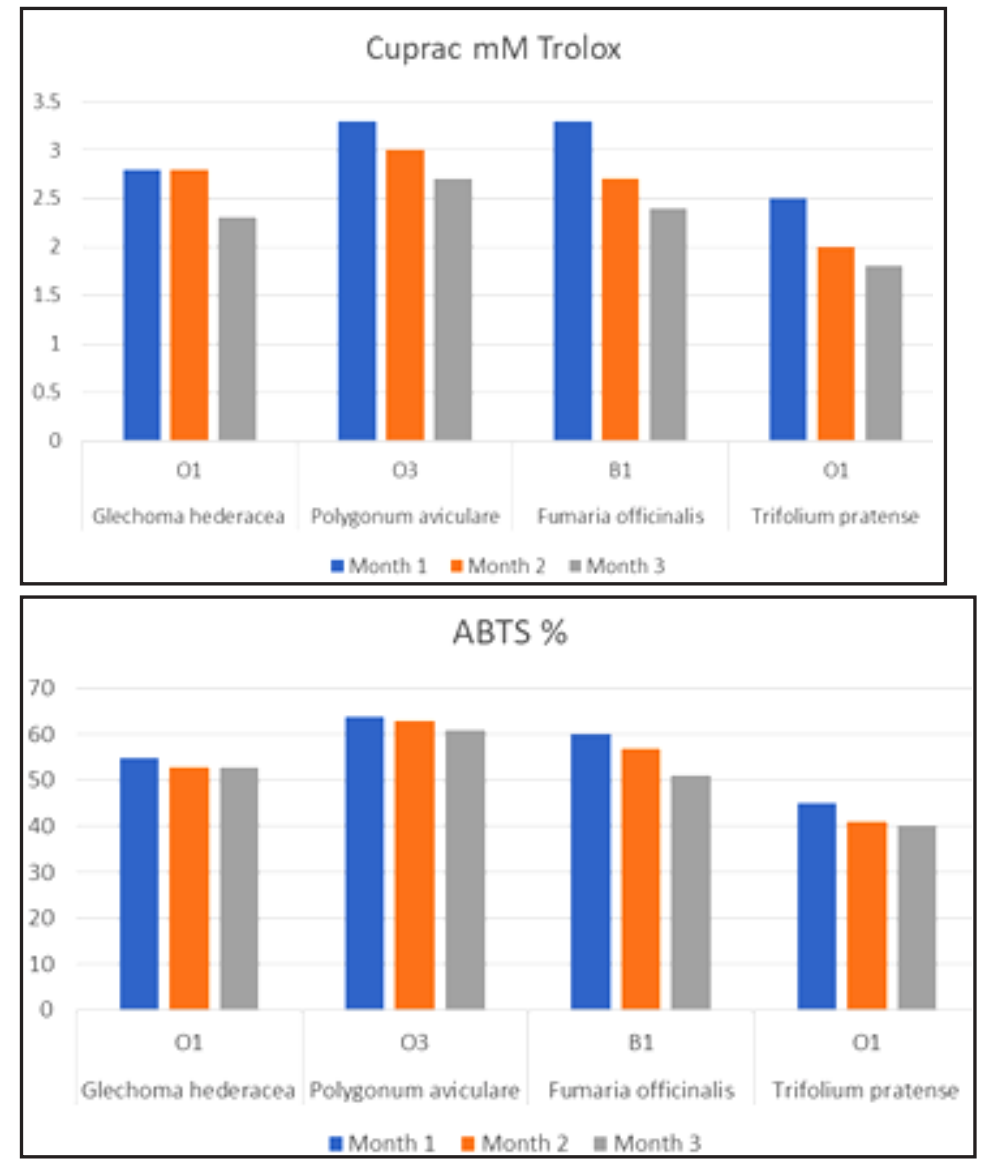

Fig. 4. Capacity of reducing CUPRAC radicals (Cuprac $\mathrm{mM}$ Trolox)

Fig. 5. Capacity of reducing ABTS (\%)

\section{Conclusions}

By analyzing the obtained results, clear correlation between pedoclimatic conditions and the polyphenols and flavonoids content of studied species can be observed, especially in the beginning of the vegetation period. Polygonum aviculare and Fumaria officinalis have the highest antioxidant capacity out of all the studied species. We will continue our studies concerning these species in order to be able to include them in a topical pharmaceutical formulation, which could be used to prevent the oral cavity diseases.

\section{References}

1.RANDHAWA, R.K., GUPTA, N., ARORA, V., GUPTA, P., Internat. J. Contemporary Medical Res., 2, no. 1, 2015, p .53.

2.BUNGAU,S., TIT,D.M., FODOR,K., CIOCA,G., AGOP,M., IOVAN,C., NISTOR, CSEPPENTO,D.C., BUMBU,A., BUSTEA, C., Sustainability, 2018, 10, no. 8, 2788. doi:10.3390/su10082788

3.SAN MIGUEL, S.M., OPPERMAN, L.A., ALLEN, E.P., ZIELINSKI, J., SVOBODA, K.K., J.Periodontology, 81, no. 11, 2010, p. 1675.

4.SAN MIGUEL, S.M., OPPERMAN, L.A., SVOBODA, K.K., FASEB, J., Meeting Abstract Suppl., 24, 2010, p. 181.

5.BHUVANESWARI, P., Sal. Pavithra. R/J. Pharm. Sci. Res., 6, no. 4, 2014, p. 206.

6.SAN MIGUEL, S.M., OPPERMAN, L.A., ALLEN, E.P., SVOBODA, K.K., Compend Cont. Educ. Dent., 32, no. 1, 2011, p. 5.

7.SCULLEY, D.V., LANGLEY-EVANS, S.C., Clin. Sci., 105, no 2, 2003, p.167.

8.PETTI, S., SCULLY, C., J. Dent., 37, no. 6, 2009, p. 413.

9.CHAPPLE, I.L.C., BROCK, G., EFTIMIADI, C., MATTHEWS, J.B., Mol.Pathol., 55, no. 6, 2002, p. 367.

10.COPOLOVICI, D., BUNGAU, S., BOSCENCU, R, TIT, D. M., COPOLOVICI, L.,Rev. Chim.(Bucharest), 68, no. 3, 2017, p. 507.
11.YEUNG, A.W.K., TZVETKOV, N., EL-TAWIL, O.S., BUNGAU, S.G., ABDEL-DAIM, M.M., ATANASOV, A.G.,Oxid. Med. Cell. Longev.,2018, 2018, ID 8278454.

12.FODOR, K., TIT, D.M., PASCA, B., BUSTEA, C., UIVAROSAN, D., ENDRES, L., IOVAN, C., ABDEL-DAIM, M., BUNGAU, S., Oxid. Med. Cell. Longev, 2018, 20118, ID 4147320, 10 pages. https://doi.org/10.1155/ 2018/4147320

13.SYED, S.B.S., MUZIB, H.R.A., GEETHA, A., Jap. J.Clin. Oncol., 34, no 7, 2004, p.379

14.ABDEL-DAIM, M.M., ZAKHARY, N.I., ALEYA, L., BUNGAU, S. G., BOHARA, R.A., SIDDIQI, N.) ., Oxid. Med. Cell. Longev., 2018, 2018, ID 2098123, 2 pages. https://doi:10.1155/2018/2098123

15.JURCA, T., MARIAN, E., TITA, B., VICAS, S., PALLAG, A., TOTH, I., KRUSPER, L., BRAUN, M., VICAS, L., Rev. Chim. (Bucharest), 68, no. 8, 2017, p. 1786

16.PALLAG, A., PASCA, B., JURCA, T., SUCIU, R., NEMETH, S., VICAS, L., Farmacia, 64, no. 3, 2016, p. 372.

17.SIRBU, V., PALLAG, A., HOENIGES, A., COJ OCARU, S.I., Rev. Chim. (Bucharest), 68, no.2, 2017, p.390.

18.TIT,D.M., BUNGAU,S., IOVAN,C., NISTOR CSEPPENTO,D.C., ENDRES, L., SAVA, C., SABAU, A.M., FURAU, G., FURAU, C., JCM, 7, no. 10, 2018, p. 297. doi: 10.3390/jcm7100297

19.MOISA,C., COPOLOVICI,L., BUNGAU,S., POP,G., IMBREA,I., LUPITU,A., NEMETH,S., COPOLOVICI, D., Farmacia, 66, no. 2, 2018, p. 289.

20.MOLYNEUX, P., J. Sci. Technol., 26, no. 2, 2004, p. 211

21.MRAZ, C., MURESAN, M., MICLE, O., VICAS, L., PALLAG, A., COLTAU, M., PUSCAS, I., Farmacia, 60, no. 2, 2012, p. 264.

22.PALLAG, A.,FILIP, G.A., OLTEANU, D., CLICHICI, S., BALDEA, I., JURCA, T., MICLE, O., VICAS, L., MARIAN, E., SORITAU, O., CENARIU, M., MURESAN, M., Oxid. Med. Cell. Longev., 2018, ID 3060525, 14 pages, https://doi.org/10.1155/2018/3060525.

23.CERUTTI, P.A., Lancet, 344, 1994, p.862.

24.TULIPANI, S., MEZZETTI, B., CAPOCASA, F., BOMPADRE, S., BEEKWILDER, J., DE VOS, C.H.R., CAPANOGLU, E., BOVY, A., BATTINO, M., J. Agric. Food Chem., 56, no. 3, 2008, p 696. 
25.PALLAG, A., JURCA, T., SIRBU, V., HONIGES, A., JURCA, C., Rev.Chim.(Bucharest), 69, no. 2, 2018, p. 445.

26.PALLAG, A, JURCA, T., PASCA, B., SIRBU, V., HONIGES, A., COSTULEANU, M., Rev.Chim.(Bucharest), 67, no 8, 2016, p 1623.

27.PALLAG, A., BUNGAU, S.G., TIT, D.M., JURCA, T., SIRBU, V., HONIGES, A., HORHOGEA, C., Rev. Chim.(Bucharest), 67, no. 3, 2016, p. 530. 28.GHOLIVAND, M.B., PIRYAEI, M., Afr. J. Biotehnol., 13, no. 10, 2014, p. 1131.

29.BOEING, H., BECHTHOLD, A., BUB, A.,ELLINGER, S., HALLER, D., KROKE, A, LESCHIK-BONNET, E., MANFRED, J., MULLER, M.J., OBERRITTER, H., SCHULZE, M., STEHLE, P., WATZL,B., Eur. J. Nutr., 51, no. 6, 2012, p. 637.

30.PAPUC, C., CRIVINEANU, M., NICORESCU, V., PREDESCU, C., Rev. Chim.(Bucharest), 61, no. 7, 2012, p. 619.

31.KIM, D., CHUN, O., KIM, Y., MOON, H., LEE, C., J. Agric. Food Chem., 51, 2003, p. 6509.

32.SINGLETON, V.L., ROSSI, J.A., Am. J. Enol. Viticult., 16, 1965, p.144. 33.BERTALANIC, L., KOSMERL, T, ULRICH, N.P., CIGIC, B., J. Agric. Food Chem., 60, no. 50, 2012, p. 11282.

34.WANG, T.C., CHUANG, Y.C., KU, Y.H., Food Chem., 102, 2007, p. 1163.

35.KARAMAN, S., TUTEM, E., BASKAN, K.S., APAK, R., Food Chem., 120, no. 4, 2010, p. 1201.
36.YUAN, W., ZHOU, L.J., DENG, G.R., WANG, P., CREECH, D., LI, S.Y., USA. Pharm. C., 2, 2011, p. 11.

37.TALAZ, O., GULCIN,I., GOKSU, S., SARACOGLU, N., Bioorg. Med. Chem., 17, 2009, p. 6583.

38.HU, C., KITTS, D.D., J. Agric. Food Chem., 48, 2000, p.1466.

39.KUKRIC, Z., TOPALIC-TRIVUNOVIC, L., PAVICIC, S., ZABIC, M., MATOS, S., DAVIDOVIC, A., Chem. Ind. Chem. Eng. Quarterly, 19, no 1, 2013, p. 37.

40.BRAND-WILLIAMS, W., CUVELIER, M.E., BERSET, C., LebensmWiss Technol., 28, 1995, p. 25.

41.BECHIR, A., SIRBU, R., PACURAR, M., PODARIU, A.C., MONEA, M., BECHIR, E.S, GHERGIC, D.L., Rev. Chim. (Bucharest), 65, no.3, 2014, p. 362.

42.GHERGIC, D.L., ANDREESCU, C., SIRBU, R., LECA, M.: Obtinerea preparatelor retard de clorhexidina in matrice colagenica pentru aplicatii locale in tratamentul afectiunilor parodontale, Ed. Printech, Bucuresti, 2006, p. 92, ISBN (10) 973-718-602-8.

43.SIRBU, R., BECHIR, A., NEGREANU-PIRJ OL, T., SAVA, C., NEGREANUPÎRJ OL, B., ZAHARIA, T., URSACHE, C., STOICESCU, R.M., Chemistry $\&$ Chemical Engineering, Biotechnology, Food Industry, 2011, vol. 12, No. 3, pp. 221.

Manuscript received: 14.12 .2018 